$$
\begin{gathered}
\text { UNIVERSIDADE DE SÃO PAULO } \\
\text { FACULDADE DE ECONOMIA, ADMINISTRAÇÃO E CONTABILIDADE } \\
\text { DEPARTAMENTO DE ECONOMIA } \\
\text { PROGRAMA DE PÓS-GRADUAÇÃO EM ECONOMIA }
\end{gathered}
$$

\title{
Self-employment in the United Kingdom: The role of frictions and labor market institutions
}

O emprego por conta própria no Reino Unido: o papel das fricções e das instituições do mercado de trabalho 
Prof. Dr. Vahan Agopyan

Reitor da Universidade de São Paulo

Prof. Dr. Fábio Frezatti

Diretor da Faculdade de Economia, Administração e Contabilidade

Prof. Dr. José Carlos de Souza Santos

Chefe do Departamento de Economia

Prof. Dr. Ariaster Baumgratz Chimeli

Coordenador do Programa de Pós-Graduação em Economia 


\title{
ÍTALO DE PAULA FRANCA
}

\section{Self-employment in the United Kingdom: The role of frictions and labor market institutions}

O emprego por conta própria no Reino Unido: o papel das fricções e das instituições do mercado de trabalho

\author{
Dissertação apresentada ao Departamento de \\ Economia da Faculdade de Economia, Admi- \\ nistração e Contabilidade da Universidade \\ de São Paulo como requisito parcial para a \\ obtenção do título de Mestre em Ciências.
}

Orientador: Profa. Dra. Renata Del Tedesco Narita

Versão Corrigida

São Paulo

2018 


\section{FICHA CATALOGRÁFICA}

Elaborada por Rafael Mielli Rodrigues - CRB-8/7286

Seção de Processamento Técnico do SBD/FEA/USP

Franca, Ítalo de Paula

Self-employment in the United Kingdom: the role of frictions and labor market institutions / Ítalo de Paula Franca. - São Paulo, 2018.

$51 \mathrm{p}$.

Dissertação (Mestrado) - Universidade de São Paulo, 2018.

Orientador: Renata Del Tedesco Narita.

1. Economia do trabalho 2. Política de emprego 3. Trabalhador autônomo 4. Impostos I. Universidade de São Paulo. Faculdade de Economia, Administração e Contabilidade. II. Título.

$\mathrm{CDD}-331$ 
Ao meu pai, Pedro Oseas da Franca (in memoriam), falecido durante as provas do primeiro semestre. Mesmo em lágrimas, seu exemplo me ensinou a continuar persistindo.

À minha mãe, Aureliana de Paula Franca, minha irmã, Gabriela de Paula Franca, e namorada Priscila Rocha pelo apoio incondicional. 


\section{Acknowledgements}

Agradeço imensamente a minha orientadora Profa. Renata Narita, pela paciência, exigência, orientação e apoio. Seu suporte foi fundamental para a realização deste trabalho, além de um grande aprendizado que obtive durante este percurso. Mesmo em momentos árduos, obrigado por acreditar em minha capacidade.

Agradeço ao CNPq pelo apoio financeiro durante o mestrado. Agradeço a FEA/USP por oferecer um mestrado de qualidade e todas as condições necessárias.

Agradeço a todos os amigos, colegas e familiares que de alguma forma me ajudaram durante esses anos. Todos foram muito importantes. 

"Every day you may make progress. Every step may be fruitful. Yet there will stretch out before you an ever-lengthening, ever-ascending, ever-improving path. You know you will never get to the end of the journey. But this, so far from discouraging, only adds to the joy and glory of the climb." 



\section{Abstract}

Desenvolvemos um modelo de busca por emprego que inclui o trabalhador autônomo e a riqueza para estudar a escolha ocupacional no Reino Unido. No Reino Unido, o trabalho por conta própria vem crescendo desde o início da década de 2000 e ultrapassou $14 \%$ da força de trabalho em 2015. Estimamos o modelo usando o método de momentos e dados de duas pesquisas longitudinais, a Wealth and Assets Survey e a Understanding Society, para o período 2010-12. Em seguida, utilizamos o modelo para simular políticas contrafactuais de incentivo ao emprego através do empreendedorismo, com a menor tributação de lucros, redução às barreiras de entrada no trabalho por conta própria, ou através de alterações no imposto salarial e auxílio desemprego. Os resultados mostram que um aumento do emprego autônomo pode estar associado principalmente a um aumento do imposto sobre os salários ou a uma redução do imposto sobre o rendimento do trabalho por conta própria.

Palavras-chave: Economia do trabalho. Política de Emprego. Trabalhador autônomo. Impostos. 



\section{Abstract}

We develop a job search model with self-employment and savings to understand occupation choice in the United Kingdom (UK). In the UK, self-employment has steadily grown from the beginning of the 2000s and comprised more than $14 \%$ of the workforce in 2015 . We estimated the model using the method of moments and data from two longitudinal surveys, the Wealth and Assets Survey and the Understanding Society for the period 2010-12. We then use the model to simulate counterfactual policies to promote employment via entrepreneurship such as lower profit taxation and entry barriers into self-employment, or through changes in wage taxes and unemployment benefits. The results show that a rise in self-employment can be mostly associated with an increase in the payroll tax or a reduction on the self-employment income tax.

Key-words: Labor economics. Employment Policy. Self-employment. Taxes. 



\section{Lista de ilustrações}

Figure 1 - Share of self-employed workers (\% of the workforce) . . . . . . . . 21

Figure 2 - Results from the model estimation . . . . . . . . . . . . 35

Figure 3 - Model hazard rate . . . . . . . . . . . . . . . 36

Figure $4-$ Value Functions by Job status . . . . . . . . . . . . . . 36 



\section{Lista de tabelas}

Table 1 - Composition of the workforce $(\%) \ldots \ldots \ldots 24$

Table 2 - Descriptive statistics by job status - wave $2(2010-11) \ldots \ldots 25$

Table 3 - Employment transitions $(\%) \ldots \ldots \ldots$

Table 4 - Simulation results: Changes in Labor Taxes . . . . . . . . . . . . . . 40

Table 5 - Simulation results: Changes in the Degree of Search Frictions and Unemployment Benefits . . . . . . . . . . . . . . . . . 41

Table 6 - Model without Self-employment - Simulation results . . . . . . . . . . 42

Table A.1-Characteristics of workers . . . . . . . . . . . . . . . . 49

Table A.2-Income and taxes by net wealth quintile (Annual Average) . . . . . . . . 50

Table A.3-Parameter values . . . . . . . . . . . . . . . . . . 50

Table A.4-Regression: probability to leave unemployment . . . . . . . . . . . . 51 



\section{Sumário}

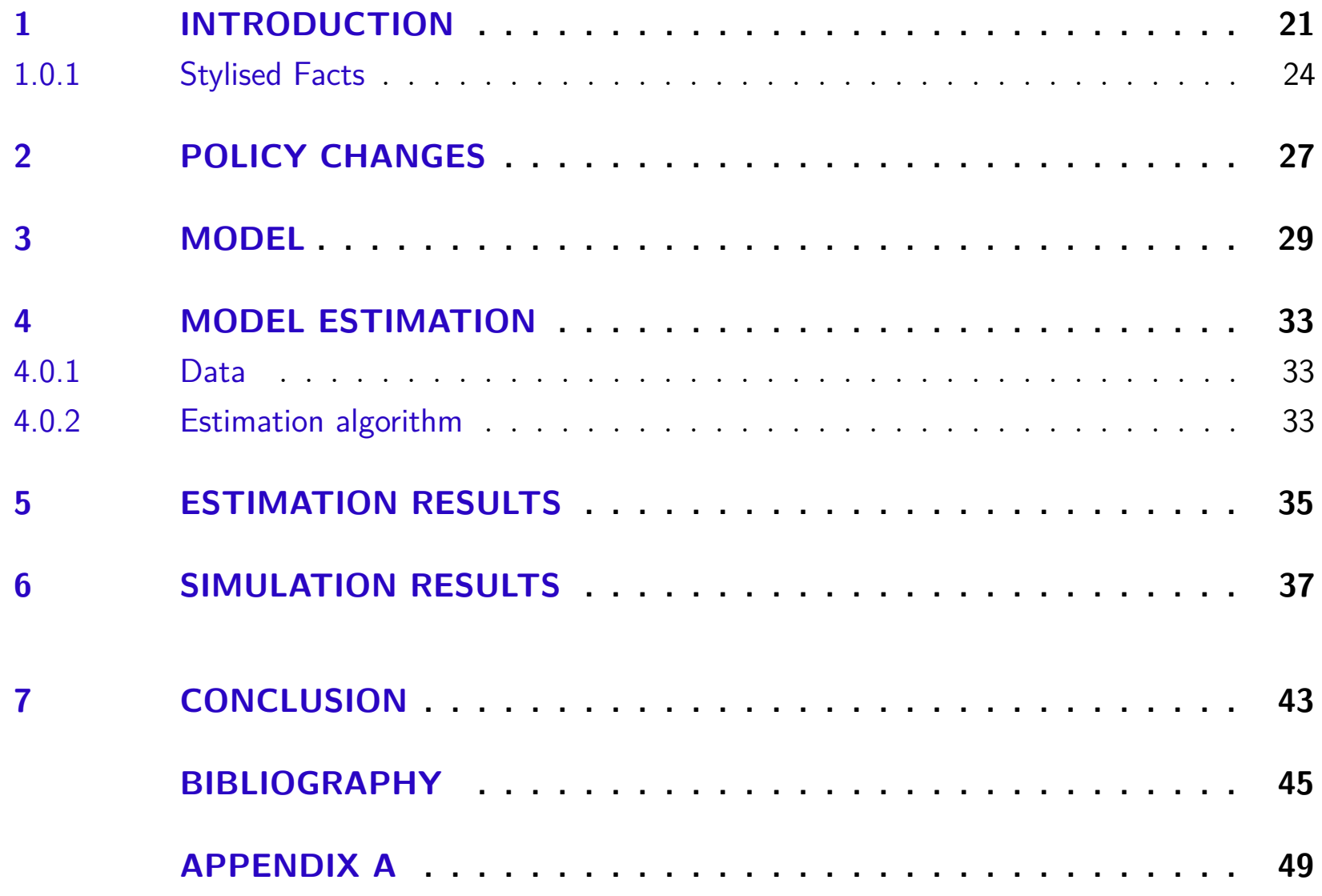





\section{Introduction}

Self-employment is a relevant and growing part of the labor market in the United Kingdom (UK), as well as a recurring issue of debate regarding its impact on both the workforce and the economy. ${ }^{1}$ Self-employment accounted for one-third of employment growth since 2010 and corresponded to more than $14 \%$ of the workforce in 2015 . The growth in self-employment in the UK is also one of the highest among OECD countries. As shown in Figure 1, this contrasts with other large developed economies - the US and Germany - where self-employment as a percentage of the workforce is smaller and declines over time. ${ }^{2}$

Figure 1 - Share of self-employed workers (\% of the workforce)

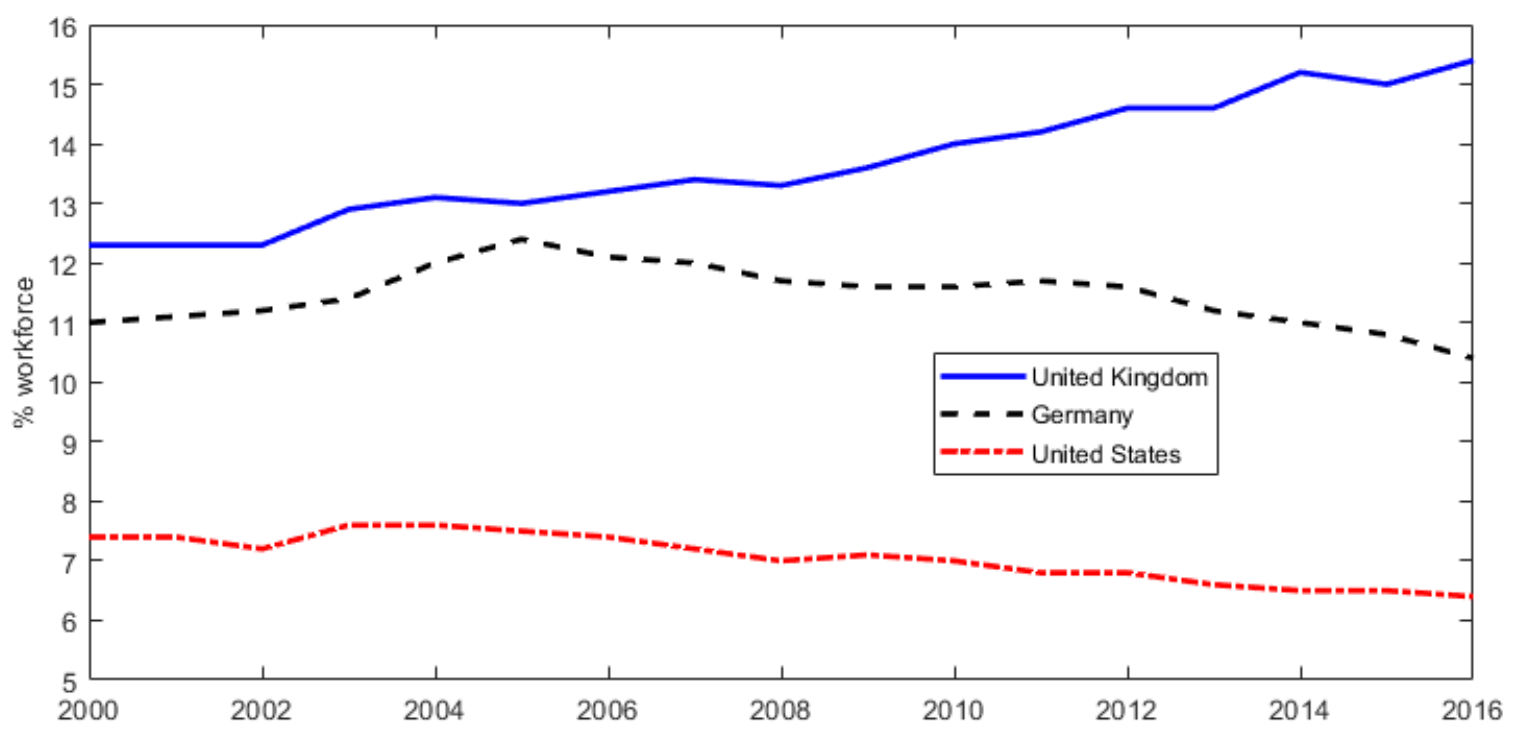

Source: OECD data.

It is often argued that individuals sort into self-employment because (i) they do not find a job opportunity as a wage earner, (ii) they prefer the option of self-employment rather than being wage earner as a response to labor market regulations, and (iii) they cannot grow as a firm and employ other workers. The latter possibility is the focus of several papers in the entrepreneurship literature ${ }^{3}$ while the first two are explicitly addressed by very few papers in the literature (e.g. Narita 2018 and Bobba et al. 2018).

In this study, we examine the role of labor market policies and incentives to becoming self-employed in explaining the self-employment trend over the period 2009-2016. After 2009,

$1 \quad$ See for example Tatomir 2015

2 Data from OECD (2018), doi: < http://dx.doi.org/10.1787/fb58715e-en> (Accessed on 09 February 2018).

3 Lucas 1978, Evans e Jovanovic 1989, Jovanovic 1994, Buera, Kaboski e Shin 2011, Allub e Erosa 2014 are some examples. See Quadrini 2009 for a survey on papers on entrepreneurship. 
the government introduced a series of schemes to encourage people to start their own business by providing (social and financial) capital as well as easing taxation on micro-entrepreneurs. In absence of other changes that increased the value of salaried jobs or unemployment, these changes should have induced individuals to accept more often the self-employment option, whenever that appears.

We develop a job search model with savings and endogenous search effort to investigate how labor market frictions, savings and institutional characteristics drive occupation choice in the UK. Thus, we can investigate how labor market frictions, savings and institutional characteristics drive occupation choice in the UK. The model distinguishes among three types of workers: paid employed, self-employed, and unemployed. We estimate this using the method of moments on UK data from two longitudinal surveys, the Wealth and Assets Survey (WAS), and the Understanding Society survey, for the period between 2010 and 2012.

Then we use the model to investigate the impact of alternative policies on employment. The results show that a $10 \%$ increase in the tax on wages raises the self-employment rate by $7.9 \mathrm{pp}(64 \%)$. A $10 \%$ reduction in the self-employment income tax similarly generates an increase in self-employment by 5.5pp (44\%). An improvement in self-employment opportunities (through higher entry probability) is another source to its own growth. A $20 \%$ higher probability of entry into self-employment from unemployment leads to a 1.3pp (11\%) increase in the self-employment fraction. In all these cases, the rise in self-employment corresponds to a decline in paid employment, while unemployment also decreases. The UK has recently changed wage subsidies and income tax policies, so these results illustrate the importance of having a model of occupation choice including all three job states, endogenous effort, and heterogeneity in wealth for conducting policy analysis.

Our model extends Lentz 2009 by including self-employment and allowing workers to decide whether to accept a job opportunity or remain unemployed after an arrival shock. In the model, unemployed workers decide how much to search for a job, comparing the expected gains in moving to self-employment or to employment. Due to search frictions, workers can choose how much they want to save in order to avoid income fluctuations, and this indirectly affects (via search-effort) the probability of getting a job offer and the opportunity to start a business.

A few studies incorporate entrepreneurship or self-employment in an environment with search frictions. For instance, Albrecht, Navarro e Vroman 2009 follow the DiamondMortensen-Pissarides search and matching framework and model a developing economy in which workers can be formal wage earners, informal self-employed or unemployed. Workers are heterogeneous in the formal sector by productivity and are homogeneous while self-employed. Another approach with self-employment and search is taken in Poschke 2012 who develops an occupation choice model with frictions in the matching between firms and employees, and unemployed workers that can become self-employed as a firm, depending on a reservation productivity. Similarly, Kumar e Schuetze 2007 and Bradley 2016 develop search models 
with the idea of the self-employed as employers. Bradley 2016 distinguishes between the self-employed as own-account workers and recruiters. Millán 2012 calibrates an on-the-job search model with self-employment, paid employment, and unemployment. She considers that job offers and entry opportunities to become self-employed arrive exogenously unlike this study. None of these studies incorporate savings or endogenous search effort.

The literature about self-employment/entrepreneurship in developed economies associates it to financial capital. Typically they find that financial capital is positively related to starting a business in rich countries (for example, Evans e Jovanovic 1989, Holtz-Eakin, Joulfaian e Rosen 1994, Blanchflower e Oswald 1998, Quadrini 2000, Bernhardt 1994, Carrasco 1999, Buera 2009 and Cagetti e Nardi 2006). Hurst e Lusardi 2004 however find that wealth does not have an impact on business entry for the majority of households in the US. In contrast, Disney e Gathergood 2009 find some evidence of a relationship between 'shocks' to house value and subsequent entry into self-employment in the UK. Using the recently available UK Wealth and Assets survey, Sauer e Wilson 2016 find strong liquidity constraints on entrepreneurship amongst single women. This is in part attributed to their lower likelihood to obtain formal loans explained by lower rates of home ownership and thus a lack of collateral.

In addition, there are many studies devoted to analyzing the determinants of selfemployment. For instance, Hurst e Pugsley 2011 and Parker 2004 find that self-employment is associated with jobs giving more satisfaction, having more flexibility, independence, and the possibility of greater income and capital accumulation. Self-employment can be linked to innovation and new job creation (Acs 2008). On the other hand, there is also evidence that the self-employed are not well remunerated compared to the paid employees (Hamilton 2000, Kawaguchi 2002). Meager e Bates 2001 show that self-employment income distribution is the most polarized across jobs. Kumar e Schuetze 2007 argue that the differential in self-employment earnings can arise due to frictions in the labor market and the low costs associated with opening one's own business. Finally, Evans e Leighton 1989 showed that unemployed individuals and low-paid workers are more likely to become entrepreneurs.

In the following subsection, we discuss the empirical facts regarding the labor market in the UK. Section 2 describes the main labor market policy changes in the past decade. Section 3 presents the model. Section 4 provides details on the model estimation and data. Section 5 contains the estimation results. In Section 6, we present the simulations. Finally, Section 7 concludes. 


\subsubsection{Stylised Facts}

This subsection shows some key aspects of the UK labor market, that the proposed model intends to capture. Table 1 shows the composition of the workforce from the Understanding Society survey. The proportion of self-employed workers has increased since 2009 (wave 1), reaching more than $14 \%$ of the labor force in wave 7 , that corresponds to interviews between 2015 and 2016. While the fraction of workers in paid employment remained around 78 to $79 \%$, the proportion in unemployment declined over the same period.

Table 1 - Composition of the workforce (\%)

\begin{tabular}{lccccccc}
\hline \hline Job Status & $\mathbf{2 0 0 9 - 1 0}$ & $\mathbf{2 0 1 0 - 1 1}$ & $\mathbf{2 0 1 1 - 1 2}$ & $\mathbf{2 0 1 2 - 1 3}$ & $\mathbf{2 0 1 3 - 1 4}$ & $\mathbf{2 0 1 4 - 1 5}$ & $\mathbf{2 0 1 5 - 1 6}$ \\
\hline Paid employed & 78.1 & 78.9 & 78.7 & 78.8 & 79.5 & 78.5 & 79.2 \\
Self-employed & 12.2 & 12.4 & 13.0 & 13.1 & 13.4 & 14.0 & 14.2 \\
Unemployed & 9.7 & 8.6 & 8.3 & 8.0 & 7.1 & 7.5 & 6.6 \\
\hline
\end{tabular}

Notes: We calculated the proportion in any job status considering all workers in the Understanding Society survey. The samples include all individuals between the ages 18 and 75 years. We use waves one to seven, each corresponding to a two-year interval from 2009-10 until 2015-16, respectively.

Table A.1 in the appendix shows the proportion of self-employment by age, education, gender and sector. From this table we observe that the fraction of self-employed with college degree has grown over the years. It represented $28.2 \%$ of the self-employed in 2009-10, changing to $32.8 \%$ in $2015-16$. In addition, there has been an increase in the fraction of older individuals (>45 years old) and women, although self-employment is still predominantly male.

Table 2 summarizes the main descriptive data by job status. Comparatively, we observe that on average the self-employed workers (SE) are older, predominantly male, have lower income, lower education, and their net wealth is higher, although more dispersed than that of individuals in paid employment (PE). Compared with the two types of workers, the unemployed (UN) have the lowest level of education, age and wealth. In addition, the self-employed in the UK are found working in construction (19\%) followed by education $(8 \%)$ and then transportation $(6 \%)$, whereas those workers in paid employment are typically found in education (12\%), retail trade (11\%) and health services (9\%) sectors. Table A.1 shows how the distribution of the self-employed across sectors evolved since 2009. We see a decline of the share in construction and retail that appears to be compensated by an increase in the share in education/sports activities from 2010 to 2014, transportation and communication/entertainment since 2014. From this table, we observe that the fraction of wage workers in construction has also declined overtime, education/sports activities have also increased from 2010 to 2014, health services have grown since 2010, while retail and transportation are fairly constant. 
Table 2 - Descriptive statistics by job status - wave 2 (2010-11)

\begin{tabular}{|c|c|c|c|}
\hline Variable & $\mathrm{PE}$ & $\mathrm{SE}$ & UN \\
\hline Age (mean) & 40.8 & 46.7 & 37.1 \\
\hline Males $(\%)$ & 46.9 & 68.9 & 56.9 \\
\hline College Degree (\%) & 42.1 & 39.3 & 19.4 \\
\hline $\mathrm{n}=$ & 26,337 & 4,153 & 2,885 \\
\hline \multicolumn{4}{|c|}{ Main sectors - composition } \\
\hline First & Education $^{*}(12 \%)$ & Construction (19\%) & - \\
\hline Second & Retail trade $(11 \%)$ & Education* $(8 \%)$ & - \\
\hline Third & Health Services (9\%) & Transportation $(7 \%)$ & - \\
\hline \multicolumn{4}{|c|}{ Gross annual main job income $^{a}(£)$} \\
\hline Minimum & 1,644 & 520 & - \\
\hline Maximum & 109,200 & 150,000 & - \\
\hline Mean & 23,622 & 20,626 & - \\
\hline Std Dev & 16,770 & 20,416 & - \\
\hline \multicolumn{4}{|l|}{ Net Wealth $^{b}(£)$} \\
\hline Minimum & $-4,602$ & $-3,865$ & $-4,620$ \\
\hline Maximum & $1,899,845$ & $1,902,879$ & $1,831,500$ \\
\hline Mean & 253,536 & 346,523 & 142,944 \\
\hline Std Dev & 274,480 & 340,017 & 221,736 \\
\hline
\end{tabular}

Notes: The sample includes all individuals between the ages 18 and 75 . We denote Paid Employment by PE, Self-employment by SE and Unemployment by UN. (i) All the characteristics of the workers are calculated using the Understanding Society survey. (ii) Wealth and income data have been taken from the Wealth and Assets Survey (WAS). We trimmed the $1 \%$ bottom and top of wealth and income data. * Education and Sport activities. ${ }^{a}$ Employment income ${ }^{b}$ Net wealth $=$ Net financial wealth + All Properties Total value financial liabilities.

In Table A.2, in the appendix, we present the worker's mean gross income, net income and effective taxes paid by net wealth quintile. The table shows that the self-employed earn less than the paid employees in all quintiles. Both income and taxes rise monotonically with wealth however the tax on self-employment income varies less from the first to the fourth quintile, only showing a significant increase for those self-employed in the highest wealth quintile.

Table 3 presents the employment transition of the workers between 2010-11 and 2011-12. In a year, this table shows that the job destruction probability is $1.9 \%$ for the self-employed and $2.4 \%$ for the paid employed. The job finding probability with a firm is $23.6 \%$ and $4.0 \%$ as self-employed. In the yearly data, many transitions appear as job-to-job moves, which may have occurred with at least some period of unemployment in between jobs. While we do not ignore that job-to-job transitions may be important in the data, we do not model them in this study. 
Table 3 - Employment transitions (\%)

\begin{tabular}{l|ccc}
\hline \hline & \multicolumn{3}{|c}{$\mathbf{2 0 1 1 - 1 2}$} \\
\cline { 2 - 4 } $\mathbf{2 0 1 0 - 1 1}$ & Self-Employed & Paid Employed & Unemployed \\
\hline Self-Employed & 91.7 & 6.4 & 1.9 \\
Paid Employed & 1.5 & 96.1 & 2.4 \\
Unemployed & 4.0 & 23.6 & 72.4 \\
\hline
\end{tabular}

Note: We tracked individuals between two survey waves and calculated the employment transitions conditional on the job status in 2010-2011. Data from Understanding Society survey, waves 2 and 3.

In Appendix Table A.4, we report the regression estimates of the relationship between wealth and transitions out of unemployment, controlling for age, gender and interactions with education. We use two different specifications, one that looks at transitions from unemployment to paid-employment, reported in columns 1 and 3, and another that analyses transitions from unemployment to self-employment, reported in columns 2 and 4. Columns 1 and 2 display estimates for the unemployed without college degree while columns 3 and 4 show estimates for the unemployed with college degree. The results in columns 1 and 2 show that exit from unemployment is positively associated with wealth. The level of wealth is stronger in determining exits to self-employment than to paid-employment. The coefficient of wealth-squared is negative suggesting that the relationship between wealth and transitions out of unemployment is non-linear. Separating the sample for those with and without college reveals that college education is potentially a substitute for wealth such that assuming a standard search model (without capital) for modeling individuals with college would make sense. However, because the majority of the unemployed have less than college degree, a search model with capital makes more sense. 


\section{Policy Changes}

In the next paragraphs, we document the main changes in employment policies in the UK.

New Enterprise Allowance (NEA). This program was implemented in April 2011 to encourage individuals to start or grow their own businesses. It was introduced for long-term unemployed workers (26 or more weeks) who are over age 18 and receive Jobseeker's Allowance (JSA), the unemployment insurance scheme. This rule was changed in October 2012, and the worker can now claim the NEA from day one in unemployment. The participant obtains access to a mentor who provides guidance and financial support during the development of her business plan and through the first six months of the business. If the plan is approved, the participants are eligible for a state subsidy for the first 26 weeks. Since October 2013, they could also apply for capital loans. In 2015, eligibility expanded to include other assistance programs: Employment and Support Allowance, Incapacity Benefit, Income Support and Universal Credit.

According to official statistics, from April 2011 to December 2015, the NEA included 160,420 individuals and 80,830 new businesses were created. Currently, there is a discussion regarding the expansion and reform of the NEA to support a larger group of self-employed workers beginning with the lowest earners who tend to benefit more from the support.

Access to credit. The Enterprise Finance Guarantee (EFG) was launched in 2009 by the government-owned British Business Bank. It provides loans to smaller businesses with a government-backed $75 \%$ guarantee against the outstanding facility balance, promoting access to credit. The EFG has supported the provision of over 28,000 business loans, at an average value of around $£ 105,000$, to a value of over $£ 3$ billions to smaller businesses in the UK (as at end of September 2017).

Incentives to youth employment. The Prince's Trust Enterprise Programme (PTEP) was launched in 1983 to provides training and financial support for young people (18-30 year olds) who are found to have more difficulty to start their own business because they have less access to financial loans and less experience.

Income tax. Since 2010, the base rate has remained at 20\% per year, the highest rate was $40 \%$ per annum for incomes above $£ 37,400$ in 2010 and $£ 31,785$ in 2015. In 2010, a new top rate of $50 \%$ was introduced on income over $£ 150,000$ a year, but it was then cut to $45 \%$ in April 2013. From 2010 to 2015, the amount of income each individual is entitled to receive without taxes each year (Personal Allowance) grew 54\%, reaching $£ 10,600$ per year. Income and payroll tax changes could change self-employment rates by making it more or 
less attractive than wage work. A number of studies have analyzed the impact of changes in the average taxation on the self-employment rate. Moore 1983 found that a $10 \%$ increase in the payroll tax liability caused a 5 to $8 \%$ increase in the probability of being self-employed in the US. Using US 1970 Census data, Long 1982 found that a 10\% increase in the average income tax rate increased the self-employment rate by 6.4\%. Parker 1996 used a 1959 to 1991 time-series of United Kingdom data and shows that higher marginal income tax rates were found to increase self-employment rates. Bruce 2000 exploits variations in the tax treatment of wage and self-employment income using the Panel Study of Income Dynamics. Interestingly, he shows that the differential taxation has significant effects on the probability of making a transition into self-employment. Reducing an individual's marginal tax rate on self-employment income while holding his marginal wage tax rate constant reduces the probability of entry. Conversely, reducing his relative average tax rate in self-employment increases this probability by a smaller amount. Such evidence is consistent with theoretical predictions that higher marginal income tax rates increase the payoff to evading or avoiding taxes by under-reporting business income (Robson e Wren 1999).

Working tax credit. The working tax credit (WTC) was introduced in April 2003 with the intention to increase the incentives to work. This program replaced the Working Families Tax Credit (WFTC), which operated from April 1999 until March 2003. Blundell et al. 2000 studied the impact of WFTC on hours and participation. They find that WFTC and associated reforms increased lone parents' employment by 3.6 percentage points and decreased by less than one percentage point the fathers' employment, with the reforms encouraging households to have one earner rather than two. Overall, their results are consistent with a small rise in the number of workers mainly driven by single parents. The self-employed with a low income may qualify to receive the WTC. However, the rules were tightened in 2005 for self-employed workers with stricter requirements to obtain the benefit ${ }^{3}$. For the paid employed the rules remained the same since its introduction, just updating the benefit values throughout time. The Universal Credit (UC) is a social security benefit introduced in 2013. It is intended to replace six other benefits, such as Child Tax Credit, Income Support, WTC, and others. So far, there is no evaluation of effects on the UC program on labor participation and the composition of workforce.

3 In 2015 the definition of self-employment changed to "a person that is engaged in the carrying on of a trade, profession or vocation." From April 2015, new self employed claimants have been required to demonstrate that they are trading on a commercial basis and that their business is conducted with a view to achieving profits, organised and regular. 


\section{Model}

The model contemplated here is based on Lentz 2009, modified to introduce the self-employment. Workers live infinitely and maximize their discounted stream of future utility by choosing how much to consume and search for work, facing a risk of job loss. Individuals can smooth consumption over time at a rate $r$ through the use of their savings. This is the only instrument available here. They discount time at a subjective rate $\rho$.

There are three employment states: Paid employment $(e)$, Self-employment $(s)$, Unemployment $(u)$. If the worker is unemployed she receives $b$, that includes unemployment benefits. If it is paid employed, she receives a fixed wage $w$ net of tax or subsidies, $T(w)$, and if self-employed she receives the business profit $\pi^{s}\left(k_{t}\right)$ that depends on the worker's capital, after the taxes or subsidies, $T\left(\pi^{s}\right)$. Importantly, we allow for entry into self-employment or employment to arrive both exogenously (through $\lambda$ shocks) and endogenously through (1) search effort and (2) the decision of individuals between accepting the job or continuing in the unemployment state.

\section{The decision problem can be written as:}

$$
\begin{aligned}
& \max _{c_{t}, \xi_{t}} \underset{t}{\mathrm{E}} \sum_{t=0}^{\infty}(1+\rho)^{-t}\left[u\left(c_{t}\right)-e\left(\xi_{t}\right)\right] \\
& \text { s.t: } \quad k_{t+1}=(1+r) k_{t}+\mathbb{1}\left(n_{t}=e\right)(w(1-T(w)))+\mathbb{1}\left(n_{t}=s\right)\left(\pi^{s}\left(k_{t}\right)\left(1-T\left(\pi^{s}\right)\right)+\right. \\
& +\mathbb{1}\left(n_{t}=u\right) b-c_{t}, \\
& c_{t} \geq 0, \xi_{t} \geq 0, \\
& k_{t} \in[\underline{k}, \bar{k}], \\
& \operatorname{Pr}\left(n_{t+1}=u \mid n_{t}=e\right)=\delta_{e}, \quad \operatorname{Pr}\left(n_{t+1}=u \mid n_{t}=s\right)=\delta_{s}, \\
& \operatorname{Pr}\left(n_{t+1}=e \mid n_{t}=u\right)=\lambda_{e} \xi_{t} \mathbb{1}\left(V_{e}\left(k_{t+1}\right)>V_{u}\left(k_{t+1}\right)\right), \\
& \operatorname{Pr}\left(n_{t+1}=s \mid n_{t}=u\right)=\lambda_{s} \xi_{t} \mathbb{1}\left(V_{s}\left(k_{t+1}\right)>V_{u}\left(k_{t+1}\right)\right) .
\end{aligned}
$$

This is valid for all time $t . \mathbb{1}$ is an indicator function according to the current job status. $c_{t}$ is the consumption, $k_{t}$ is the worker's wealth, $\xi_{t}$ is the search effort intensity, $n_{t}$ is the employment state. $\lambda_{i}$ is the base job offer arrival rate, and $\delta_{i}$ is the job destruction rate, $i \in\{\mathrm{e}, \mathrm{s}\}$. As in Lentz 2009, we do not consider on-the-job search. In other words, there are no direct transitions between self-employment and employment. We assume that for the worker to make this transition, she must be unemployed for at least a short period of time.

We assume that the utility and search cost function have the following characteristics: 


$$
\begin{gathered}
u^{\prime}(\cdot)>0 \text { and } u^{\prime \prime}(\cdot)<0 \\
e(0)=0, \quad e(\cdot)>0 \text { and } e^{\prime \prime}(\cdot)>0
\end{gathered}
$$

The model can be solved recursively. For each level of $k, V_{e}(k)$ is the maximal present value of being employment, $V_{s}(k)$ is the maximal present value of being self-employed, and $V_{u}(k)$ corresponds to the maximal for unemployed worker. $k^{\prime}$ is the level of wealth chosen in the subsequent period. The Bellman equations can then be written as:

$$
V_{e}(k)=\max _{k^{\prime}}\left\{u\left((1+r) k+w(1-T(w))-k^{\prime}\right)+\frac{\delta_{e} V_{u}\left(k^{\prime}\right)+\left(1-\delta_{e}\right) V_{e}\left(k^{\prime}\right)}{1+\rho}\right\}
$$

$$
V_{s}(k)=\max _{k^{\prime}}\left\{u\left((1+r) k+\pi^{s}(k)\left(1-T\left(\pi^{s}\right)\right)-k^{\prime}\right)+\frac{\delta_{s} V_{u}\left(k^{\prime}\right)+\left(1-\delta_{s}\right) \max \left[V_{s}\left(k^{\prime}\right), V_{u}\left(k^{\prime}\right)\right]}{1+\rho}\right\}
$$

$$
V_{u}(k)=\max _{k^{\prime}, \xi \geq 0}\left\{u\left((1+r) k+b-k^{\prime}\right)-e(\xi)+\right.
$$

$$
\left.+\frac{\lambda_{e} \xi \max \left[V_{e}\left(k^{\prime}\right), V_{u}\left(k^{\prime}\right)\right]+\lambda_{s} \xi \max \left[V_{s}\left(k^{\prime}\right), V_{u}\left(k^{\prime}\right)\right]+\left(1-\lambda_{s} \xi-\lambda_{e} \xi\right) V_{u}\left(k^{\prime}\right)}{1+\rho}\right\}
$$

The policy functions are the savings when unemployed, $k_{u}(k)$, the savings when selfemployed, $k_{s}(k)$, and the savings when employed $k_{e}(k)$. Finally, a choice of search intensity, $\xi(k)$, is made by the individual when she is unemployed.

The optimal search-effort level is calculated from the first-order condition:

$$
e^{\prime}(\xi(k))=\frac{\lambda_{e} \max \left[V_{e}\left(k^{\prime}\right)-V_{u}\left(k^{\prime}\right), 0\right]+\lambda_{s} \max \left[V_{s}\left(k^{\prime}\right)-V_{u}\left(k^{\prime}\right), 0\right]}{1+\rho}
$$

All sufficient conditions to solve the model are identical to Lentz 2009. ${ }^{4}$ An interesting result of the model is that the gains to search diminish as wealth increases. In the model we use the CRRA utility function with parameter $\alpha$ and a strictly convex search cost function.

$$
u(c)=c^{1-\alpha} /(1-\alpha)
$$

$4 \quad$ Lentz e Tranaes 2005 demonstrate that the optimal search intensity is decreasing in wealth when assumed a separable utility function between consumption and search effort. These conditions ensure concavity of the value functions. Their numerical solutions yield a global concavity functions. We also obtain global concavity over several numerical solutions. 


$$
e(\xi)=\frac{e_{0} \xi^{\gamma}}{\gamma}, e_{0} \geq 0, \gamma \geq 0
$$

The government budget, $B(k)$, is given in equation 3.4. In this economy, we assume that the government collects labor taxes while pays subsidies and the unemployment benefit. For each level of capital, the stocks are defined as $P E$ for paid employment, $S E$ for selfemployment and $U$ for unemployment. In steady state, the flow in and out from each state is balanced, so that the stocks are obtained.

$$
B(k)=T(w) w \cdot P E(k)+T\left(\pi^{s}\right) \pi^{s}(k) \cdot S E(k)-b \cdot U(k)
$$





\section{Model Estimation}

\subsubsection{Data}

We use annual data from two UK longitudinal surveys to estimate the model. The first is the Wealth and Asset Survey (WAS), a longitudinal survey that began in 2006 and collects annual information on the level of assets, labor income, savings and debt, as well as on basic individual characteristics such as education, gender, and age. The model was estimated using the wave 3, that corresponds to interviews that started anytime in the period 2010-12. From the WAS, we use wealth and income data.

The second source of data is from the Understanding Society ${ }^{5}$. Beginning in 2009 this is a large and comprehensive survey collecting information on approximately 40,000 households (at wave 1) in the United Kingdom. Households recruited at the first round of data collection are visited each year to collect information on changes to their household and individual circumstances. Interviews are carried out face-to face in respondents' homes by interviewers or through a self-completion online survey. Young people aged 10-15 complete a youth questionnaire, whilst respondents aged 16 and over complete the adult survey. The overall purpose of the Understanding Society is to cover subjects such as work, education, income, and health. Here we take advantage of the yearly data on job status with which we construct the conditional probabilities of transition between unemployment and each working state. We use the waves 2 and 3 comprising individuals interviewed sometime in 2010-11 and a year later in 2011-12.

The two surveys are comparable in terms of income data, however only the WAS contain the wealth variable. The average of annual net income is $£ 16,924$ in wave 2 (2010-11) of Understanding Society survey and $£ 16,637$ in the WAS for the period 2010-12.

\subsubsection{Estimation algorithm}

We use the method of moments to recover the base job offer rates $\lambda_{e}$ and $\lambda_{s}$, and the search cost function parameter $\gamma$. The job destruction rates $\delta_{e}$ and $\delta_{s}$ are from data, and do not depend on the workers choice. To estimate the parameters $\left(\gamma, \lambda_{e}, \lambda_{s}\right)$ we use the following procedure. For each guess of $\gamma$, we obtain $\Lambda=\left(\lambda_{e}, \lambda_{s}\right)$ and other objects of the model using fixed point iteration. Specifically, we

1. Define initial values for $\Lambda$,

2. We set up a discrete grid for $k$ using minimum and maximum from the data,

3. Define initial values for the value functions $V_{u}(k), V_{s}(k)$ and $V_{e}(k)$,

5 This survey continued the well-known British longitudinal survey, the British Household Panel Survey (BHPS). 
4. Update the value functions using (3.i), (3.ii) and (3.iii),

5. Update $\Lambda$ using:

$$
\lambda_{i}=\frac{\hat{\operatorname{Pr}}\left(n_{t+1}=i \mid n_{t}=u\right)}{\int \xi(k) \mathbb{1}\left(V_{i}\left(k_{t+1}\right)>V_{u}\left(k_{t+1}\right)\right) d H(k)},
$$

where $H(k)$ represents the cumulative distribution function of capital, that we obtain from the data, and $i \in\{\mathrm{e}, \mathrm{s}\}$.

6. Repeat the above steps for many values of $\gamma$.

Finally, we choose the search-effort cost function parameter $\gamma$ by targeting the stocks of employment in the data.

Other parameters are calibrated $\alpha$ at 1.6 based on similar values found in the macroeconomic literature for the UK and this implied $\gamma$ equal to 14.75. $e_{0}$ is normalized at one. The fraction of workers in each job status is in Table 1 . The annual interest rate $r$ is set at $5.0 \%{ }^{6}$ and the subjective discount rate at $5.1 \%$ a year. The unemployment benefit $b$ is set at $£ 3,500$ in one year, which is an average of the Jobseeker's Allowance (JSA).

The average wage of an employed worker is $£ 23,622$ (Table 2). The wage distribution is degenerated thus only the average is considered. We trim the $1 \%$ top and bottom net wealth to avoid misreporting errors, which implies a minimum of $£-3,805$ and maximum of $£ 1,902,879$ for the wealth variable. We also trim the $1 \%$ top and bottom of the self-employment and paid employed incomes, reported in Table 2. From now on, we normalize all incomes and wealth relative to wage (such that $w=1$ ). All the parameter values are shown in Table A.3.

In relation to Lentz 2009 we introduce self-employment and thus have to model their flow income. We model profits as a function of wealth according to the function (8). In order to obtain the $\beta$ parameters, we regress profit (in $\log$ ) on net wealth. We estimate:

$$
\begin{aligned}
\pi^{s}\left(k_{t}\right) & =\exp \left(\beta_{1}+\beta_{2} k_{t}\right) \\
\log \left(\text { Income }_{s e}\right) & =0.5121+0.0026 k_{t} \\
t & :[5.18]
\end{aligned}
$$

\footnotetext{
6 This corresponds to a 20-year average of the base UK rate.
} 


\section{Estimation Results}

In this section, we present the main results from the estimation. Figure 2 shows the search effort and cost as a function of wealth. As expected, we do find that an increase in the worker's net wealth reduces search-effort.

$$
\xi(k)=\left[\frac{(.)}{e_{0}}\right]^{\frac{1}{\gamma-1}}
$$

Figure 2 - Results from the model estimation

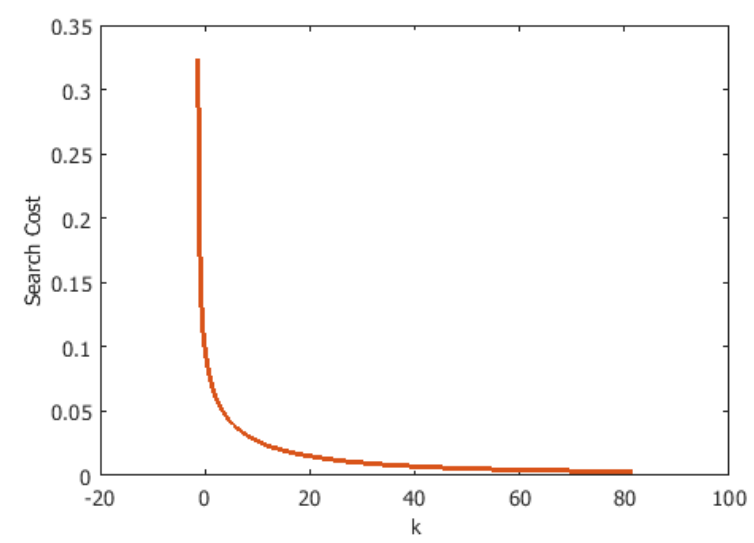

(a) Search-cost $e(\xi)$

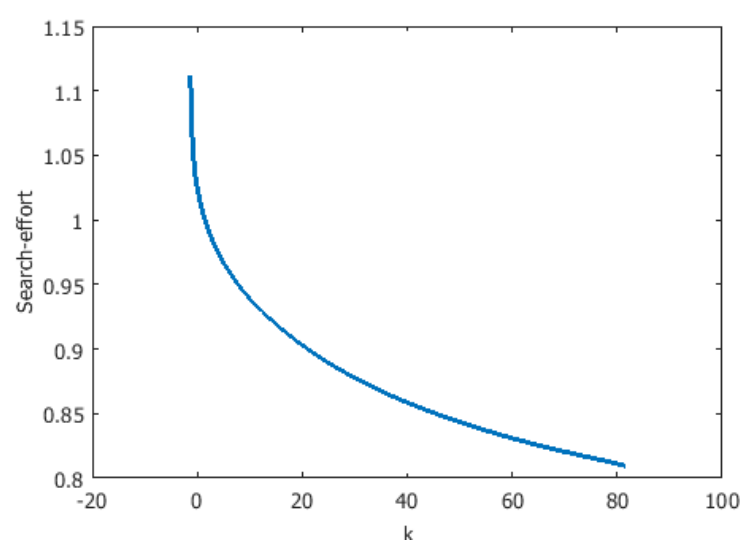

(b) Search-effort $\xi(k)$

Figure 3 shows the hazard rate for each capital level. This rate decreases until $k$ reaches 12.5. At this level, the hazard rate jumps to a rate that is $52 \%$ above the previous one, which is consistent with the value of self-employment becoming higher than the value of unemployment. Therefore, when an unemployed finds an opportunity to become self-employed, she always takes it. After this sharp increase, the rate monotonically falls as in this case the curvature and monotonicity of the value functions implied that the self-employment or employment options are always worth-taking after a certain level of capital.

Figure 4 displays the present value by job status and by each level of capital. For low levels of capital, the value of unemployment and self-employment are lower than that of paid employment. This is driven in part by the fact that wages are on average higher than the income of unemployment and profits of low capital entrepreneurs. As the level of capital increases, profits grow and the value of self-employment overtakes that of the unemployed and of paid employees. Specifically, for $k$ above 12.5, self-employment becomes more valuable 
Figure 3 - Model hazard rate

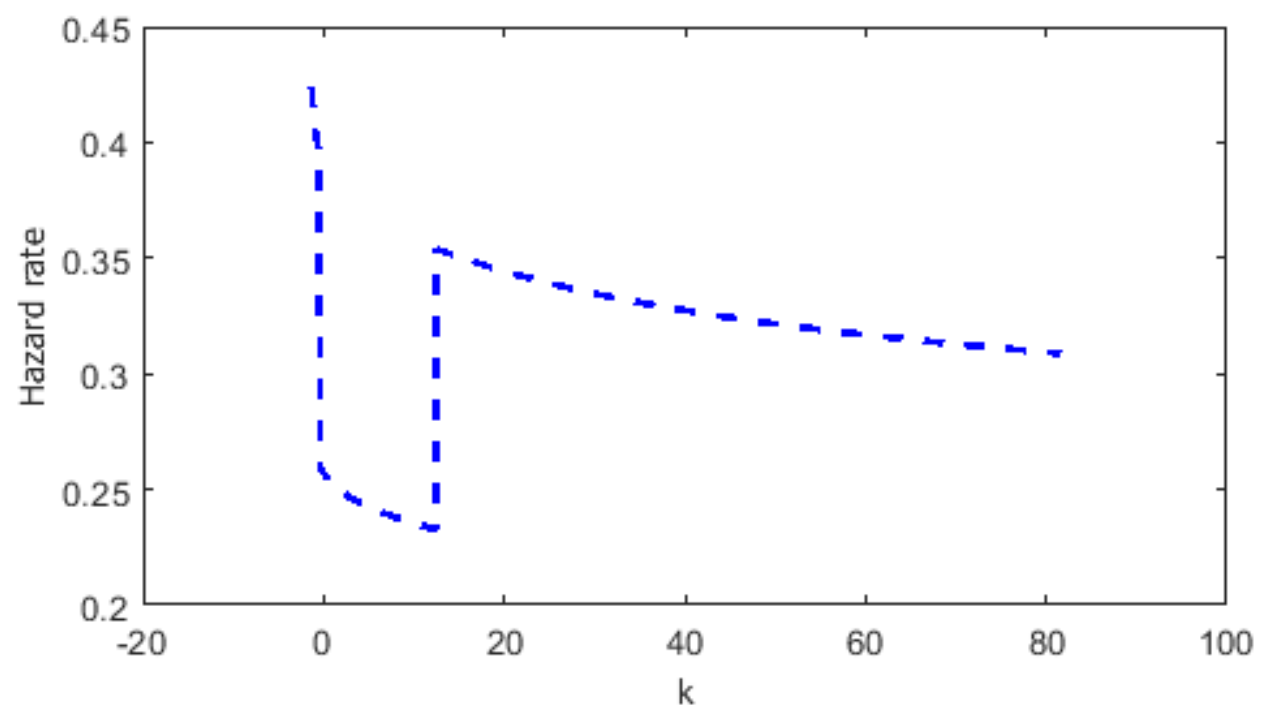

than unemployment, and for $k$ higher than 51.1, it exceeds the value of employment. This is consistent with Evans e Jovanovic 1989's model prediction and findings that liquidity constraints bind in the US data. We do not model ability as they do, however they show that even for high ability individuals capital does matter for entrepreneurship entry.

In other words, this solution shows that for low levels of capital, an individual is better off in unemployment rather than in self-employment. For medium levels of capital, the contrary but the value of employment is still the highest. For high levels of capital, an individual would achieve the highest welfare in self-employment. This result has implications on which types of policies to implement in order to increase better job opportunities through employment or self-employment. We simulate and discuss some alternative policies in the next session.

Figure 4 - Value Functions by Job status

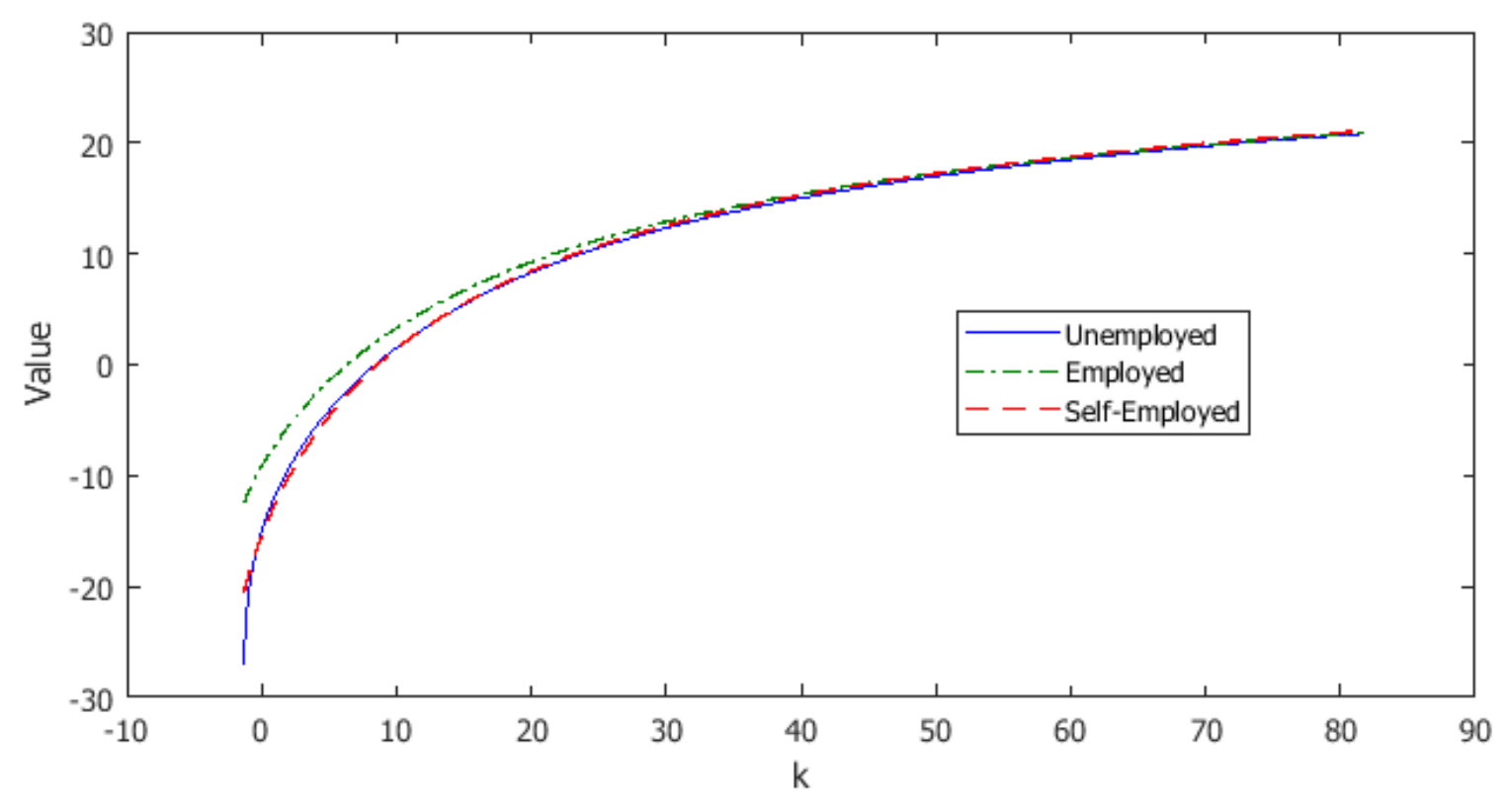




\section{Simulation Results}

In this section, we simulate the impact of different labor market policies and changes in taxes and subsidies on employment. We compare it to the baseline model estimated for the period 2010-11. We simulate reductions and increases of 10 and 20 percentage points in the modeled parameters. We also simulate the model removing the self-employment, in order to check the importance for the results of having self-employment in the model.

Table 4 shows the impact of both taxes and subsidies. A change in the taxes on wages, $T(w)$, leads to a significant variation in occupational choices. A $10 \%$ reduction causes the fraction of workers in paid employment to increase 4p.p. (5\%) and the fraction in unemployment to increase 0.4p.p. (5.1\%), while self-employment reduces by 4 p.p (35.1\%). ${ }^{7}$ The effects just get larger if a $20 \%$ reduction in the wage taxes is implemented. In this case, the fraction of self-employment goes up down by a bit more than 7p.p. As for increases in the wage taxes, we observe opposite effects however greater in magnitude. For instance, by levying taxes that are $20 \%$ higher than the benchmark, paid-employment goes down by $28 \%$, unemployment falls by $28 \%$ while the fraction in self-employment triplicates. The main reason is a large decline in the value of employment and, for workers with low and medium levels of capital, the value of self-employment is now greater than the value of employment. The value of unemployment also falls as a result of a decreasing option value of employment. Consequently, we show that increasing wage taxes are effective to reduce unemployment while simultaneously raising tax revenue. This is not the case in the next simulations of this table.

For self-employment income taxes $\left(T\left(\pi^{s}\right)\right.$ ), we consider two scenarios: (i) a flat tax change for every self-employed worker and (ii) a progressive change that implies a tax reduction only for the low-income self-employed (first and second quintiles) or a tax increase only for the high-income self-employed (fourth and fifth quintiles). We keep the revenue neutral between simulations (i) and (ii) by calibrating the tax rates accordingly. The progressive changes are motivated by recent policies that are aimed at promoting entrepreneurship with focus on low income individuals. In general, we observe that increases in either flat or progressive self-employment income taxation tend to diminish self-employment while increasing both unemployment and wage jobs. ${ }^{8}$ This is obtained because the low wealth people prefer to remain unemployed and the high-wealth ones tend to leave unemployment only to a wage job whenever this option arrives. In terms of magnitude, the effects of either type of taxation do not differ much for unemployment. For instance, a flat tax decrease of

$7 \quad$ The evidence of tax reduction (credit) effects on employment is mixed. Blundell et al. 2000 find that the Working Family Tax Credit and associated reforms increased lone parents' employment by 3.6 percentage points while it decreased by less than one percentage point the fathers' employment. Our results are thus consistent to what occurs in the sample of fathers in their study.

8 This is consistent with most empirical evidence (Moore 1983, Long 1982, Parker 1996, Bruce 2000, among others). 
$10 \%$ for all self-employed reduces unemployment by $0.5 \mathrm{p} . \mathrm{p}(6.4 \%)$ while a progressive change that keeps budget neutral (by reducing the tax by $20.75 \%$ only for the first two quintiles of income) reduces unemployment by 0.6p.p. (7.3\%). However, when taxes are reduced only to the less wealthy self-employed, we obtain the greatest increase on self-employment. Similarly, when taxes are increased only for the wealthier, the negative effect on self-employment is also magnified in relation to an equivalent flat tax increase. In more extreme scenarios (like the one in the last column of Table 4), we show that the fraction of self-employment gets close to zero. This interesting comparison allows us to conclude that policies to attenuate unemployment should not worry about the type of taxation however choosing progressive or flat taxation does matter for occupation choice, i.e. whether to work as paid or self-employed. ${ }^{9}$

In Table 5, we simulate job activation policies by changing the degree of search frictions or the generosity of the unemployment benefit. As expected, an increase in probability of having a self-employment opportunities $\left(\lambda_{s}\right)$ by 10 and $20 \%$ elevates the fraction of selfemployed workers by $6.1 \%$ and $10.6 \%$, respectively. This is compensated by a decrease in the fraction of unemployed (-0.9\% and $-1.6 \%$, respectively) and of wage workers $(-0.9 \%$ and $-1.5 \%$, respectively). Another way to understand the impact of search frictions is via changes in the search cost function. Assume proportional changes in search costs by altering $e_{0}$. We show that reducing it by 10 and $20 \%$ increases the fraction of workers in paid-employment by $0.3 \%$ and $0.8 \%$ (respectively), reduces the fraction of self-employment by $2 \%$ and $5 \%$ (respectively), while leaves unemployment almost unchanged. Thus, the impact of alleviating frictions in general is to increase wage employment whereas policies to encourage self-employment entry reduce wage employment.

Finally, Table 5 also shows the results when we varied the unemployment benefit $b$. As it changes the incentives to move into paid employment and self-employment, a reduction in $b$ leads to an increase in unemployment. For instance, when the unemployment benefit is lowered by 10 and $20 \%$ we observe a reduction in self-employment of $2.1 \%$ and $4.3 \%$ (respectively), a decline in paid-employment of $1.8 \%$ and $3.9 \%$ (respectively) and a significant rise in self-employment of $12.9 \%$ and $27.3 \%$ (respectively). This occurs because workers with low and medium levels of capital value more unemployment than self-employment in the benchmark. When the unemployment benefit falls, this is reversed, thereby increasing self-employment. On the other hand, an increment in $b$ drops the fraction of individuals in self-employment and implies an increase in both paid employment and unemployment.

Table 6 presents the simulation results after removing self-employment as a job option in the model. So we considered an artificial economy in which we only have unemployed and paid employed workers and we take the self-employed out of the estimation sample. By doing so, we observe that an increase in wage taxes, unlike in the model with self-employment, would imply a growth instead of a drop in unemployment. Hence, it is indeed the case that having

$\overline{9}$ It is possible that due to higher marginal taxation, there is more under-reporting of self-employment income, particularly at the top. In such case, self-employment rates would not go down as much as we obtained in these simulations. 
the self-employment option is an important way out of unemployment in developed economies. Interestingly, changing unemployment benefits in an economy without the self-employment has much lower impact on the unemployment or employment. This is again because workers that would switch to self-employment when the unemployment benefit increased now have to exert more effort to find wage employment, which is costly. In equilibrium, there is less variation in employment stocks in the simulations where we shut down self-employment. 


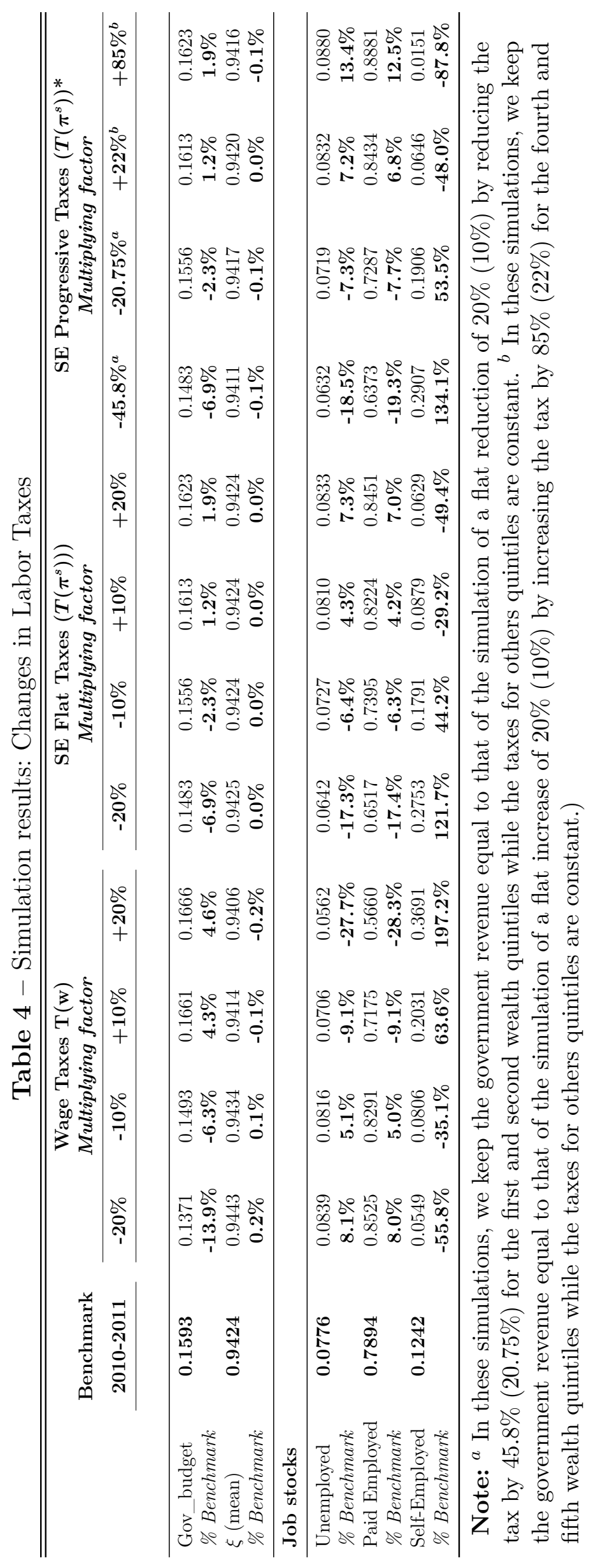




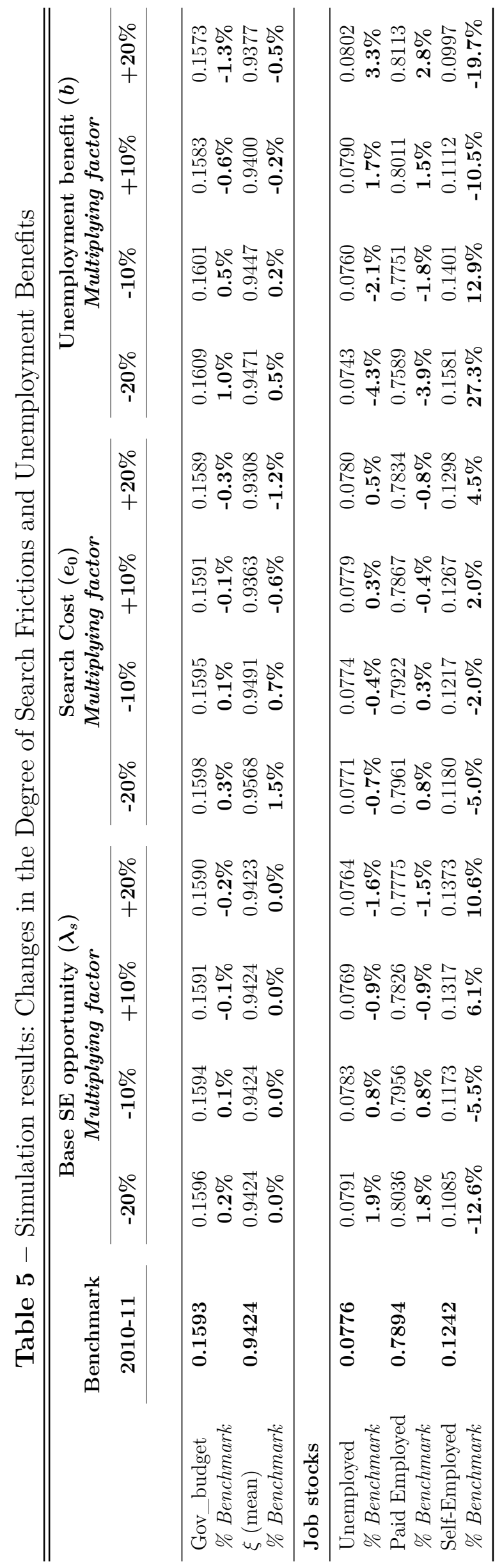




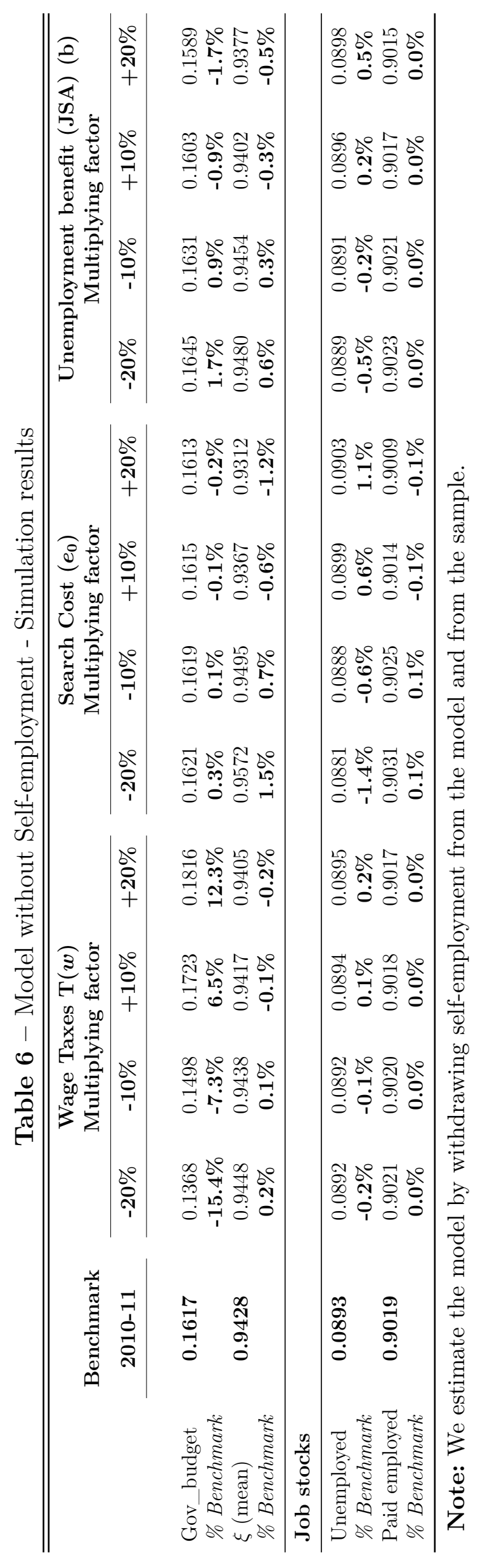




\section{Conclusion}

The UK is one of the few OECD countries to experience a significant self-employment increase in recent years. This study develops a job search model with savings and endogenous effort based on Lentz 2009 by including self-employment and allowing workers to decide whether to accept/reject a job opportunity after an arrival shock. It captures the key empirical patterns found in the UK data.

First, we show that for low levels of capital, an individual is better of in unemployment rather than in self-employment. For medium levels of capital, the opposite, but the value of employment is still the highest. For high levels of capital, an individual would achieve the highest value in self-employment, which is consistent with binding liquidity constraints.

We use the model to simulate counterfactual policies to promote employment via entrepreneurship such as lower profit taxation and entry barriers into self-employment, or through changes in wage taxes and unemployment benefits. The results show that a rise in self-employment can be mostly associated with an increase in income tax to employees, a tax reduction on self-employment income and an improvement in self-employment opportunities (through higher entry probability). In all these cases, the rise in self-employment corresponds to a decline in paid employment, while unemployment decreases.

We also showed that, ignoring self-employment in the model and in the data, some changes in labor market institutions would imply much greater impact on the unemployment rate. For instance, we find that an increase in the payroll taxes, unlike in the model with self-employment, would imply growth instead of a drop in the unemployment rate. 



\section{Bibliography}

Acs 2008 ACS, Z. J. Foundations of high impact entrepreneurship. Foundations and Trends $\AA$ in Entrepreneurship, v. 4, n. 6, p. 535-620, 2008. ISSN 1551-3114. Disponível em: $<$ http://dx.doi.org/10.1561/0300000025>. Quoted on page 23.

Albrecht, Navarro e Vroman 2009 ALBRECHT, J.; NAVARRO, L.; VROMAN, S. The effects of labour market policies in an economy with an informal sector*. The Economic Journal, Blackwell Publishing Ltd, v. 119, n. 539, p. 1105-1129, 2009. ISSN 1468-0297. Disponível em: <http://dx.doi.org/10.1111/j.1468-0297.2009.02268.x>. Quoted on page 22.

Allub e Erosa 2014 ALLUB, L.; EROSA, A. Financial frictions, occupational choice and economic inequality. 2014. Quoted on page 21.

Bernhardt 1994 BERNHARDT, I. Comparative advantage in self-employment and paid work. Canadian Journal of Economics, JSTOR, p. 273-289, 1994. Quoted on page 23.

Blanchflower e Oswald 1998 BLANCHFLOWER, D. G.; OSWALD, A. J. What makes an entrepreneur? Journal of labor Economics, The University of Chicago Press, v. 16, n. 1, p. 26-60, 1998. Quoted on page 23.

Blundell et al. 2000 BLUNDELL, R. et al. The labour market impact of the working families' tax credit. Fiscal Studies, Wiley Online Library, v. 21, n. 1, p. 75-104, 2000. Quoted 2 times on pages 28 and 37.

Bobba et al. 2018 BOBBA, M. et al. Labor market search, informality, and on-the-job human capital accumulation. R\&R Journal of Econometrics, 2018. Quoted on page 21.

Bradley 2016 BRADLEY, J. Self-employment in an equilibrium model of the labor market. IZA Journal of Labor Economics, Springer, v. 5, n. 1, p. 6, 2016 . Quoted 2 times on pages 22 and 23.

Bruce 2000 BRUCE, D. Effects of the united states tax system on transitions into self-employment. Labour economics, Elsevier, v. 7, n. 5, p. 545-574, 2000. Quoted 2 times on pages 28 and 37 .

Buera, Kaboski e Shin 2011 BUERA, F.; KABOSKI, J.; SHIN, Y. Finance and development: A tale of two sectors. American Economic Review, v. 101, n. 5, p. 1964-2002, 2011. Quoted on page 21.

Buera 2009 BUERA, F. J. A dynamic model of entrepreneurship with borrowing constraints: theory and evidence. Annals of finance, Springer, v. 5, n. 3-4, p. 443-464, 2009 . Quoted on page 23.

Cagetti e Nardi 2006 CAGETTI, M.; NARDI, M. D. Entrepreneurship, frictions, and wealth. Journal of political Economy, The University of Chicago Press, v. 114, n. 5, p. 835-870, 2006. Quoted on page 23.

Carrasco 1999 CARRASCO, R. Transitions to and from self-employment in spain: an empirical analysis. oxford Bulletin of Economics and Statistics, Wiley Online Library, v. 61, n. 3, p. 315-341, 1999. Quoted on page 23. 
Disney e Gathergood 2009 DISNEY, R.; GATHERGOOD, J. Housing wealth, liquidity constraints and self-employment. Labour Economics, Elsevier, v. 16, n. 1, p. 79-88, 2009. Quoted on page 23.

Evans 2004 EVANS, D. The elevated status of the elasticity of marginal utility of consumption. Applied Economics Letters, Taylor \& Francis, v. 11, n. 7, p. 443-447, 2004. Quoted on page 50.

Evans e Jovanovic 1989 EVANS, D. S.; JOVANOVIC, B. An estimated model of entrepreneurial choice under liquidity constraints. Journal of political economy, The University of Chicago Press, v. 97, n. 4, p. 808-827, 1989. Quoted 3 times on pages 21, 23, and 36

Evans e Leighton 1989 EVANS, D. S.; LEIGHTON, L. S. Some empirical aspects of entrepreneurship. The American Economic Review, JSTOR, v. 79, n. 3, p. 519-535, 1989. Quoted on page 23.

Hamilton 2000 HAMILTON, B. H. Does entrepreneurship pay? an empirical analysis of the returns to self-employment. Journal of Political economy, The University of Chicago Press, v. 108, n. 3, p. 604-631, 2000. Quoted on page 23.

Holtz-Eakin, Joulfaian e Rosen 1994 HOLTZ-EAKIN, D.; JOULFAIAN, D.; ROSEN, H. S. Entrepreneurial decisions and liquidity constraints. The RAND Journal of Economics, [RAND Corporation, Wiley], v. 25, n. 2, p. 334-347, 1994. ISSN 07416261. Disponível em: <http://www.jstor.org/stable/2555834>. Quoted on page 23.

Hurst e Lusardi 2004 HURST, E.; LUSARDI, A. Liquidity constraints, household wealth, and entrepreneurship. Journal of political Economy, The University of Chicago Press, v. 112, n. 2, p. 319-347, 2004. Quoted on page 23.

Hurst e Pugsley 2011 HURST, E.; PUGSLEY, B. W. What do small businesses do? [S.l.], 2011. Quoted on page 23.

Jovanovic 1994 JOVANOVIC, B. Firm formation with heterogeneous management and labor skills. Small Business Economics, 1994. Quoted on page 21.

Kawaguchi 2002 KAWAGUCHI, D. Compensating wage differentials among self-employed workers: Evidence from job satisfaction scores. ISER Discussion Paper No. 568, 2002. Quoted on page 23.

Kumar e Schuetze 2007 KUMAR, A.; SCHUETZE, H. J. Self-employment and labor market policies. Department Discussion Papers, Department of Economics, University of Victoria, v. 704, 2007. Quoted 2 times on pages 22 and 23.

Lentz 2009 LENTZ, R. Optimal unemployment insurance in an estimated job search model with savings. Review of Economic Dynamics, Elsevier, v. 12, n. 1, p. 37-57, 2009. Quoted 6 times on pages 22, 29, 30, 34, 43, and 50 .

Lentz e Tranaes 2005 LENTZ, R.; TRANAES, T. Job search and savings: Wealth effects and duration dependence. Journal of labor Economics, The University of Chicago Press, v. 23, n. 3, p. 467-489, 2005. Quoted on page 30.

Long 1982 LONG, J. E. Income taxation and the allocation of market labor. Journal of labor Research, Springer, v. 3, n. 3, p. 259-276, 1982. Quoted 2 times on pages 28 and 37. 
Lucas 1978 LUCAS, R. On the size distribution of business firms. The Bell Journal of Economics, JSTOR, p. 508-523, 1978. Quoted on page 21.

Meager e Bates 2001 MEAGER, N.; BATES, P. The self-employed and lifetime incomes: Some uk evidence. International Journal of Sociology, Taylor \& Francis, v. 31, n. 1, p. 27-58, 2001. Quoted on page 23.

Millán 2012 MILLÁN, A. The choice to become self-employed: acknowledging frictions. [S.1.]: University Carlos III Madrid, 2012. Quoted on page 23.

Moore 1983 MOORE, R. L. Self-employment and the incidence of the payroll tax. National Tax Journal, JSTOR, p. 491-501, 1983. Quoted 2 times on pages 28 and 37.

Narita 2018 NARITA, R. Self employment in developing countries: a search-equilibrium approach. R\&R Review of Economic Dynamics, 2018. Quoted on page 21.

Parker 1996 PARKER, S. C. A time series model of self-employment under uncertainty. Economica, JSTOR, p. 459-475, 1996. Quoted 2 times on pages 28 and 37.

Parker 2004 PARKER, S. C. The economics of self-employment and entrepreneurship. [S.1.]: Cambridge University Press, 2004. Quoted on page 23.

Poschke 2012 POSCHKE, M. The labor market, the decision to become an entrepreneur, and the firm size distribution. [S.1.], 2012. Quoted on page 22.

Quadrini 2000 QUADRINI, V. Entrepreneurship, saving, and social mobility. Review of Economic Dynamics, Elsevier, v. 3, n. 1, p. 1-40, 2000. Quoted on page 23.

Quadrini 2009 QUADRINI, V. Entrepreneurship in macroeconomics. Annals of Finance, Springer, v. 5, n. 3-4, p. 295-311, 2009. Quoted on page 21.

Robson e Wren 1999 ROBSON, M. T.; WREN, C. Marginal and average tax rates and the incentive for self-employment. Southern Economic Journal, JSTOR, p. 757-773, 1999. Quoted on page 28.

Sauer e Wilson 2016 SAUER, R. M.; WILSON, T. The rise of female entrepreneurs: New evidence on gender differences in liquidity constraints. European Economic Review, Elsevier, v. 86, p. 73-86, 2016. Quoted on page 23.

Tatomir 2015 TATOMIR, S. Self-employment: what can we learn from recent developments? Bank of England Quarterly Bulletin Q1, pp. 56-66, 2015. Quoted on page 21. 



\section{Appendix A}

Table A.1 - Characteristics of workers

\begin{tabular}{|c|c|c|c|c|c|c|c|}
\hline & 2009-10 & 2010-11 & 2011-12 & 2012-13 & 2013-14 & 2014-15 & 2015-16 \\
\hline \multicolumn{8}{|l|}{ Self-employed workers } \\
\hline$\%$ Males & 68.8 & 68.9 & 67.3 & 67.4 & 66.4 & 67.5 & 64.9 \\
\hline \% College Degree & 39.8 & 39.3 & 41.6 & 42.6 & 43.3 & 42.0 & 44.7 \\
\hline$\%$ Part-time & 24.7 & 25.7 & 27.3 & 26.5 & 27.6 & 22.6 & 28.3 \\
\hline$\%$ has a second job & 7.9 & 8.8 & 8.3 & 7.8 & 7.7 & 8.6 & 8.6 \\
\hline \multicolumn{8}{|l|}{$\%$ Age } \\
\hline$<35$ & 18.7 & 17.0 & 16.6 & 16.2 & 16.4 & 16.5 & 15.5 \\
\hline $35-45$ & 30.5 & 30.3 & 29.2 & 27.8 & 27.2 & 27.7 & 25.9 \\
\hline+46 & 50.8 & 52.8 & 54.2 & 56.0 & 56.4 & 55.8 & 58.6 \\
\hline \multicolumn{8}{|c|}{ Main Sector - composition \% total workers } \\
\hline Construction & 18.4 & 18.8 & 18.0 & 17.5 & 17.9 & 17.7 & 16.3 \\
\hline Education/Sports activities & 7.6 & 7.6 & 8.2 & 8.5 & 9.0 & 7.5 & 8.0 \\
\hline Transportation & 7.2 & 6.6 & 6.1 & 6.5 & 6.4 & 7.1 & 7.6 \\
\hline Retail & 6.3 & 6.4 & 6.0 & 5.5 & 5.8 & 6.0 & 5.5 \\
\hline Communication/Entertainment & 5.0 & 4.5 & 5.2 & 5.2 & 5.4 & 5.7 & 5.7 \\
\hline Voluntary/Church & 4.5 & 4.5 & 4.6 & 5.3 & 5.4 & 4.9 & 5.6 \\
\hline Restaurants & 3.5 & 3.1 & 3.2 & 3.1 & 3.0 & 2.8 & 2.9 \\
\hline Health Services & 3.3 & 3.2 & 3.4 & 3.3 & 3.9 & 3.5 & 3.9 \\
\hline Mechanical Eng. & 3.2 & 3.0 & 2.9 & 2.9 & 2.4 & 2.2 & 2.3 \\
\hline Other Services ${ }^{a}$ & 12.4 & 13.8 & 13.5 & 14.0 & 14.2 & 13.3 & 13.6 \\
\hline Other categories & 28.5 & 28.5 & 28.8 & 28.1 & 26.7 & 29.1 & 28.6 \\
\hline $\mathrm{n}=$ & 3,870 & 4,153 & 3,944 & 3,808 & 3,683 & 3,445 & 3,653 \\
\hline \multicolumn{8}{|l|}{ Paid-employed workers } \\
\hline$\%$ Males & 46.7 & 46.9 & 46.8 & 47.1 & 47.1 & 47.4 & 46.8 \\
\hline \% College Degree & 43.0 & 42.1 & 43.1 & 44.1 & 44.8 & 44.8 & 45.9 \\
\hline$\%$ Part-time & 24.2 & 24.2 & 24.3 & 23.8 & 23.3 & 22.1 & 23.1 \\
\hline$\%$ has a second job & 6.0 & 6.2 & 5.8 & 6.5 & 5.8 & 7.5 & 6.4 \\
\hline \multicolumn{8}{|l|}{$\%$ Age } \\
\hline$<35$ & 34.8 & 33.6 & 32.5 & 32.5 & 32.4 & 32.8 & 32.0 \\
\hline $35-45$ & 29.5 & 29.0 & 28.8 & 28.3 & 27.2 & 26.9 & 26.5 \\
\hline+46 & 35.7 & 37.4 & 38.7 & 39.1 & 40.4 & 40.3 & 41.4 \\
\hline \multicolumn{8}{|c|}{ Main Sector - composition \% total workers } \\
\hline Construction & 4.3 & 4.2 & 4.1 & 4.0 & 3.9 & 3.8 & 3.6 \\
\hline Education/Sports activities & 13.1 & 13.4 & 13.8 & 14.1 & 14.0 & 13.6 & 13.8 \\
\hline Transportation & 3.7 & 3.5 & 3.5 & 3.6 & 3.6 & 3.7 & 3.6 \\
\hline Retail & 11.0 & 10.7 & 10.6 & 10.8 & 10.8 & 10.9 & 10.7 \\
\hline Communication/Entertainment & 2.9 & 2.9 & 2.7 & 2.9 & 2.8 & 2.8 & 2.8 \\
\hline Voluntary/Church & 8.7 & 8.6 & 9.0 & 9.4 & 9.4 & 9.1 & 9.0 \\
\hline Restaurants & 5.3 & 5.1 & 4.8 & 4.7 & 4.9 & 5.0 & 4.9 \\
\hline Health Services & 8.9 & 9.1 & 9.1 & 9.0 & 9.1 & 9.1 & 9.6 \\
\hline Mechanical Eng. & 3.7 & 4.0 & 4.1 & 4.3 & 4.3 & 3.6 & 3.5 \\
\hline Other Services ${ }^{a}$ & 8.5 & 7.7 & 7.6 & 8.0 & 8.6 & 8.9 & 8.9 \\
\hline Other categories & 29.9 & 30.8 & 30.5 & 29.1 & 28.6 & 29.5 & 29.7 \\
\hline $\mathrm{n}=$ & 24,292 & 26,337 & 23,918 & 22,824 & 21,889 & 22,303 & 20,664 \\
\hline
\end{tabular}

Note: Data from the Understanding Society survey. 
Table A.2 - Income and taxes by net wealth quintile (Annual Average)

\begin{tabular}{lccccc}
\hline \hline Net wealth quintiles & First & Second & Third & Fourth & Fifth \\
\hline Self-Employed & & & & & \\
\hline Gross Income (£) & 16,426 & 20,543 & 19,852 & 21,940 & 24,368 \\
Net Income (£) & 13,506 & 16,522 & 16,131 & 17,635 & 18,733 \\
Taxes (\%) & 17.8 & 19.6 & 18.7 & 19.6 & 23.1 \\
\hline Paid Employed & & & & & \\
\hline Gross Income (£) & 17,174 & 21,822 & 22,925 & 25,770 & 30,420 \\
Net Income (£) & 13,253 & 16,369 & 17,042 & 18,809 & 21,551 \\
Taxes (\%) & 22.8 & 25.0 & 25.7 & 27.0 & 29.2 \\
\hline
\end{tabular}

Note: Average of income (net and gross) and taxes. Taxes are calculated by dividing net to gross income. Data from WAS, wave 2 (2010-12).

Table A.3 - Parameter values

\begin{tabular}{ccl}
\hline \hline Coefficient & Values & \multicolumn{1}{c}{ Comment/Observations } \\
\hline$\gamma$ & 14.75 & Calibrated to match Job Stocks \\
$\alpha$ & 1.60 & Risk aversion coefficient in Evans 2004 \\
$\rho$ & 0.051 & Slightly above the interest rate (same as Lentz 2009) \\
$\mathrm{r}$ & 0.05 & 25-year historical average: base UK rate \\
$e_{0}$ & 1.00 & Normalized \\
$\delta_{s}$ & 0.019 & Job destruction: Self-employment to Unemployment $^{a}$ \\
$\delta_{e}$ & 0.024 & Job destruction: Employment to Unemployment ${ }^{a}$ \\
$\lambda_{s}$ & 0.131 & Iteration estimate \\
$\lambda_{e}$ & 0.251 & Iteration estimate \\
& & \\
\hline & & \multicolumn{1}{c}{ Taxes } \\
\hline $\mathrm{T}(w)$ & 0.26 & Average wage tax \\
$\mathrm{T}\left(\pi^{s}\right)$ & 0.20 & Average self-employment income tax \\
\hline & \multicolumn{2}{c}{ SE income regression } \\
\hline & & \\
\hline$\beta_{1}$ & 0.512 & Intercept \\
$\beta_{2}$ & 0.0026 & Slope
\end{tabular}

\section{Wealth and others incomes}

\begin{tabular}{ccl}
\hline $\bar{k}$ & 81.66 & Max wealth $^{b}$ \\
$\underline{k}$ & -1.31 & Min wealth \\
$w$ & 1.00 & Normalized to one \\
$b$ & 0.148 & Jobseeker's Allowance (JSA) \\
\hline
\end{tabular}

Note: ${ }^{a}$ Data from the Understading Society survey, ${ }^{b}$ Data from the Wealth and Assets Survey. 
Table A.4 - Regression: probability to leave unemployment

\begin{tabular}{|c|c|c|c|c|}
\hline $\begin{array}{l}\text { Sample } \\
\text { Variables }\end{array}$ & $\begin{array}{c}(1) \\
\text { No college } \\
\operatorname{Pr}(u \rightarrow e)\end{array}$ & $\begin{array}{c}(2) \\
\text { No college } \\
\operatorname{Pr}(u \rightarrow s)\end{array}$ & $\begin{array}{c}(3) \\
\text { College } \\
\operatorname{Pr}(u \rightarrow e)\end{array}$ & $\begin{array}{c}(4) \\
\text { College } \\
\operatorname{Pr}(u \rightarrow s)\end{array}$ \\
\hline Wealth & $\begin{array}{c}0.0133^{* * *} \\
(0.0047)\end{array}$ & $\begin{array}{l}0.0039^{*} \\
(0.0021)\end{array}$ & $\begin{array}{c}0.0088 \\
(0.0094)\end{array}$ & $\begin{array}{l}-0.0065 \\
(0.0073)\end{array}$ \\
\hline Wealth-squared & $\begin{array}{c}-0.0003^{* *} \\
(0.0001)\end{array}$ & $\begin{array}{c}-0.0001^{*} \\
(0.0000)\end{array}$ & $\begin{array}{c}-0.0002 \\
(0.0001)\end{array}$ & $\begin{array}{c}0.0001 \\
(0.0001)\end{array}$ \\
\hline Male & $\begin{array}{l}-0.0410 \\
(0.0388)\end{array}$ & $\begin{array}{c}0.0149 \\
(0.0165)\end{array}$ & $\begin{array}{l}-0.0024 \\
(0.1002)\end{array}$ & $\begin{array}{c}0.1075 \\
(0.0737)\end{array}$ \\
\hline Age & $\begin{array}{c}0.0125 \\
(0.0078)\end{array}$ & $\begin{array}{c}0.0015 \\
(0.0028)\end{array}$ & $\begin{array}{c}0.0190 \\
(0.0240)\end{array}$ & $\begin{array}{c}0.0488^{* * *} \\
(0.0155)\end{array}$ \\
\hline Age-squared & $\begin{array}{c}-0.0002^{* *} \\
(0.0001)\end{array}$ & $\begin{array}{l}-0.0000 \\
(0.0000)\end{array}$ & $\begin{array}{l}-0.0004 \\
(0.0003)\end{array}$ & $\begin{array}{c}-0.0005^{* *} \\
(0.0002)\end{array}$ \\
\hline Observations & 604 & 604 & 103 & 103 \\
\hline R-squared & 0.0409 & 0.0219 & 0.1282 & 0.1173 \\
\hline
\end{tabular}

Note: This table reports estimates from OLS regressions. Robust standard errors in parentheses. ${ }^{* * *} \mathrm{p}<0.01,{ }^{* *} \mathrm{p}<0.05,{ }^{*} \mathrm{p}<0.1$. Data from the Wealth and Assets Survey, 2010-2012. 